\title{
THE ROLE OF BENGKULU REGIONAL SUPERVISION INSPECTORATE IN PREVENTING TAX FRAUD AT POLDA BENGKULU ENVIRONMENT
}

\author{
By :
}

Rusli Rachman, Lidia Br Karo, Herlambang

\begin{abstract}
Tax fraud is a behavior that is not justified by law, but in Regional Police (Polda) of Bengkulu the behavior is often found by the supervisory apparatus in 2019 with a total loss that has been deposited of Rp 57,668,922. In order to minimize and eliminate these behaviors, efforts and sanctions were required by the supervisory apparatus carried out by Itwasda (Regional Inspectorate Supervision) Polda Bengkulu. From this background, the problems examined were: (1) What was the role of the Itwasda Polda Bengkulu in preventing Tax Fraud within Polda Bengkulu? (2) What was the form of sanctions imposed by Itwasda Polda Bengkulu in responding to the work unit that embezzled tax money? To answer these problems, this study used descriptive research method. The type of this research was an empirical research. The sources data used were primary and secondary data. The processing data was done by editing, coding, reconstructing, systematizing then analyzing qualitatively using the deductive-inductive and inductive-deductive methods. The results showed that (1) Preventive Field was held based on the number of findings related to tax fraud in 2019 and has been running quite well and effectively. In addition, Itwasda Bengkulu has also made innovations in the form of activities such as Prawasrik (Pre Supervision and investigation), Verification Team of Perwabkeu (Financial Accountabilty) and Internal Coordination improvement (2) Repressive Field was in the form of Wasrik activities by providing findings along with recommendations on the object of inspection. The result concluded that the number of findings in the field of taxation and deprivasion was increasingly reduced.
\end{abstract}

Key Words: Supervision, Tax Fraud, Itwasda Polda Bengkulu 


\section{A. INTRODUCTION}

\section{Research Background}

The purpose of the Republic of Indonesia stated in the opening of the 1945 Constitution of the Republic of Indonesia is to protect the entire nation of Indonesia and the whole of Indonesia's blood and to promote public welfare, educate the nation's life and participate in carrying out world order. The basic thoughts contained in realizing social justice for all Indonesian people based on Pancasila and the 1945 Constitution. ${ }^{1}$ Achieving these goals requires substantial funding. Sources of state funding generally come from natural and human resources, one of which is tax revenue. Natural resources will be increasingly reduced, therefore tax collection is the main choice.

Indirect tax revenue aims to improve the prosperity and welfare of the community. According to Rochmat Soemitro in Mardiasmo, "tax is a people's contribution to the

\footnotetext{
${ }^{1}$ Pembukaan Undang-Undang Dasar Negara Republik Indonesia Tahun 1945
}

State Treasury based on law that can be forced by not getting lead services (contraperformance) which can be directly shown and used to pay public expenses". ${ }^{2}$ But not many people can feel what they have released. In addition, it is said that tax revenues increase every year, while the country's spending is still not so felt by the public. If this continues, it is feared that it will result in people's reluctance to pay taxes and will even tend to embezzle taxes. $^{3}$

Tax fraud is illegal because it violates applicable laws or regulations. However, members of the national police consider it reasonable to carry out tax evasion because on the one hand there are many actions that should not be carried out by leaders/head of work unit and/or treasurers who often misuse tax funds for personal or group interests. With this, taxpayers are not reluctant to

\footnotetext{
${ }^{2}$ Mardiasmo, Perpajakan Edisi Revisi, Yogyakarta. Andi Publisher. 2011

${ }^{3}$ Pulungan. 2015. "Pengaruh Keadilan, Sistem Perpajakan, Dan Kemungkinan Terdeteksinya Kecurangan Terhadap Persepsi Wajib Pajak Mengenai Etika Penggelapan Pajak (Tax Evasion)". JOM FEKON Vol 2 No 1. Universitas Riau
} 
carry out tax evasion because they assume the tax burden that will be issued will not be managed properly, so the assumption of such behavior is ethical and reasonable. ${ }^{4}$

The Government Internal Supervisory Apparatus (APIP) in Polda Bengkulu is carried out by the Regional Inspectorate Supervision (Itwasda) in an effort to monitor the performance of the organizational units within its control. In the analysis and evaluation results of 2019 submitted by the Inspector of the Bengkulu Regional Police Supervision (Irwasda Polda Bengkulu) in the Field of Budget and Financial Management which is the target of research implied that;

$$
\begin{aligned}
& \text { throughout } 2018 \text { to } \\
& 2019 \text {, in } 2018 \text { there } \\
& \text { were } 19 \text { tax fraud cases } \\
& \text { with the total of loss of } \\
& \text { Rp. 15,050,876-. In } \\
& 2019 \text {, there were } 31 \text { tax } \\
& \text { fraud cases with the } \\
& \text { total of loss of Rp. } \\
& 57,668,922.5
\end{aligned}
$$

${ }^{4}$ Indriyani, Nurlela, Wahyuningsih 2016 "Effect of Justice, Taxation System, and the Possibility of Fraud Detection of Individual Taxpayers' Perceptions of Tax Evasion". Seminar Nasional IENACO ISSN : 2337-4349.

${ }^{5}$ Data obtained from Sub-division of Renmin Itwasda Polda Bengkulu
The numbers above indicated that Itwasda Polda Bengkulu performance especially in preventing tax fraud was not optimal. Polri (National Police) bureaucratic reform would be realized if the governance system did not provide opportunities for Collusion, Corruption, and Nepotism $(K K N)$ practices especially with Head of work unit/Treasurer cases that deliberately embezzled the taxes.

Based on the background described, the researcher was interested in examining with the title "The Role of Bengkulu Regional Supervision Inspectorate in Preventing Tax Fraud at Polda Bengkulu Environment"

\section{Identification of Problems}

Based on the background description above, the problems in this study were:

1. What was the role of Itwasda Polda Bengkulu in preventing tax fraud at Polda Bengkulu?

2. What was the form of sanction imposed 


by Itwasda Polda
Bengkulu in
responding to the
work unit that
embezzled tax
money?

B. RESEARCH METHODOLOGY

\section{Research Type}

This research applied descriptive research, "that is, to describe precisely the characteristics of an individual, the condition or symptoms of a particular group" ${ }^{6}$. It meant that this research aimed to describe phenomena that exist in society.

\section{Type of Research}

$$
\begin{aligned}
& \text { In this study, } \\
& \text { researchers applied the } \\
& \text { empirical legal research, in } \\
& \text { order to obtain adequate and } \\
& \text { factual results. It was done to } \\
& \text { get data directly from } \\
& \text { respondents about what was } \\
& \text { done related to the problem to } \\
& \text { be studied. }
\end{aligned}
$$

\section{Data Sources}
Primary data were obtained by interviewing respondents in Polda Bengkulu with consideration that it would be easy for the researchers to

obtain in conducting interviews, distributing questionnaires and other data collecting. While secondary data was obtained from books, regulations and legislation.

\section{Population and Samples}

\section{a. Population}

In this study the population was all members of Itwasda Polda Bengkulu that were considered to be competent to understand and master the role of the Polda Bengkulu in the prevention of tax fraud in Polda Bengkulu.

b. Sample

Samples were
subsets of or part of the
population. ${ }^{7}$ Determination
of the sample in this study
was a purposive sampling
method where the sample
was selected and
determined by researchers
based on the criteria of
experience and skills of
respondents as members of
the National Police that
were closely related to the
problem to be studied, with

${ }^{7}$ Ibid, pg. 119. 
the focus of the research location was the Work Unit in Polda Bengkulu.

Based on the description above, the samples in this study were:

1) Irbid II (National

Intellegent

Agency) of

Itwasda Polda

Bengkulu;

2) 5 Auditors of Itwasda Polda Bengkulu;

3) Kaur Keu (Head of Financial Affairs) at Itwasda Polda Bengkulu;

4) 5 Kaur/Baur $\mathrm{Keu}$ within the Itwasda Polda Bengkulu.

Then the researchers

did distributing questionnaires and direct interviews to the samples.

\section{Data Collection Techniques}

In finding and getting the data needed in writing this thesis, the following data collections were used:

\section{a. Primary data}

This research was conducted directly based on field data collected by interviewing and distributing

questionnaires to respondents who have been determined in this study.

\section{b. Secondary Data}

It was a source obtained from the results of data that has been processed by others in order to strengthen the data obtained, it needed the references from library materials as a source of literature consisting of, they were (1) Books, used as additional references and support in the authors conducting studies library and data analysis. (2) The writings, used as secondary data are legal writings in the form of journals 


and scientific
papers. (3) Internet
articles, the author
needed to study
documents because
the data would be
obtained from a
useful literature
study for the
perfection of the
results of the
research to be
carried out

\section{Data Processing Techniques}

All data obtained was collected according to the focus of the study, both research data obtained from the results of field research and the results of library research, and then grouped to process by using the following methods:

a. Examination of Data (Editing), i.e. to correct whether the data collected is sufficiently complete, correct, clear and in accordance with the problems the author examined such as interviews and questionnaires.

b. Data Marking (Coding), are the activity of grouping or categorizing data by classifying and classifying dedicated field data that is adjusted to the items that are the focus of the study.

c. Data Reconstruction (Reconstructing), i.e. rearranges sequential orderly, logical, so it is easy to understand.

d. Data Systematization (Systematizing), which places the data according to a systematic framework based on the order of the problems. $^{8}$

After the data was collected, the author corrected the data by checking the completeness of the data in accordance with the problem, after that it provided notes or special signs based on the data source and the formulation of the problem, then rearranged the sequence regularly so that it became an understandable problem, by setting the data accordingly systematically in accordance with the order of problems, so as such, a conclusion can be drawn as a result of research.

\section{Data Processing Techniques}

After the data collected through study that had been done, then the data was analyzed qualitatively by using

\footnotetext{
${ }^{8}$ J. Supranto, Metode Penelitian Hukum dan Statistik, Rineka Cipta, Jakarta, 2003, Pg. 132.
} 
the method of thinking deductive to inductive and inductive to deductive. The deductive thinking method is an analysis that is general to specific. While the inductive thinking method is an analysis that is specific to the general.

Data obtained both from library research and from field research were analyzed descriptively qualitatively. Qualitative descriptive analysis is a method of analyzing data that groups and selects data obtained from field research according to its quality and truth, then linked to theories, principles and legal norms obtained from library studies, so the problems are answered.

After the data were analyzed one by one and arranged systematically, it answered the problems examined and then presented in the form of a thesis.

C. RESULTS AND DISCUSSION

1. The Role of Itwasda in Preventing Tax Evasion in the Bengkulu Regional Police

The role of the Itwasda Polda Bengkulu in the context of preventing tax fraud in Polda Bengkulu are implementing various policies carried out in solving violations of the law, especially in the field of taxation and the most effective way was through changes in behavior and organizational culture that gives more attention to these actions. The role of implementing the policy was carried out by Irwasda and all its members, which is carried out in the form of implementing:

a. Prawasrik

Prawasrik activities are activities in the form of consultations related to the main issues in the current year in anticipation of irregularities in the use of the budget and tax fraud. One of the important fundamental questions answered after the implementation of Prawasrik activities in the past year was: was the role of Itwasda in the form of innovative

Prawasrik activities useful for the bearers of financial functions in the taxation 
field?

The majority of members $(70 \%)$ found the breakthrough to be very useful considering that they were the front guard in the financial sector in their respective work units, only (20\%) rated the activity as having an ordinary impact and only (10\%) stated that it had no impact, so the possibility of tax fraud was reduced after the activity was carried out because it was given material about the latest rules and how to implement them properly.

b. Perwabkeu Verification Team

Departing from

Perkap Number 2 of 2013 concerning SPI (Internal Survisory Unit) within the Indonesian National Police written in Article 4 verse (2) reads internal control as referred in verse (1), the National Police Chief delegates control authority to the Kasatker (Head of work unit) and in Article 8 verse (1) reads Every Kasatker in Polri environment is responsible for the effectiveness of the implementation of SPI in their respective work environments. Then a team was formed at the work unit level, which was the Commitment Making Officer $(P P K)$, which in fact, as an extension of the Kasatker/KPA, was tasked to examine the completeness of the specific financial administration that became the concern in the form of tax fraud and management of State finances that were expected to be able to maintain financial accountability. To find out the extent of the effectiveness of the team formed, the researchers conducted a distribution of pieisoners and obtained data $(20 \%)$ stated normal, (20\%) stated useful and $(60 \%)$ considered useless. This was because the verifiers $(P P K$ of each disatker) tend to neglect orders to foster financial accountability, many were 


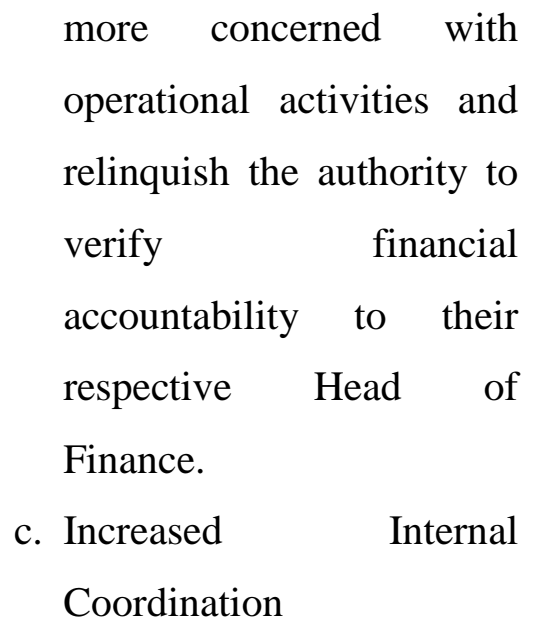

The supervision is one of the requirements for success in carrying out general tasks properly. The success of this supervision would ultimately cause the supervision itself to grow into behavior inherent in the work procedures, and develop into a culture or a new culture for officers. So the handling must involve all parties concerned. For this reason, the handling is coordinated, both the Police officers and the related work units. This policy can be implemented in increasing internal coordination. In this connection explained by the Facility and Infrastructure Auditor, KOMPOL Amri stated:

\begin{abstract}
"When I become a resource person, what I have ordered by the leadership will be mentioned in every opportunity, both at the Bidkeu (Finance) event, namely the preparation and presentation of Financial Statements and the preparation of the ideal, indicative, temporary and Ro Rena definitive $P A G U$ (Planning Bureau), thus the data presented by the work unit and the territory remains in accordance with the specified legal rules. Or if ordered to compile material to be presented by the leadership (Irwasda), I will paste the matter ordered yesterday."
\end{abstract}

From the results of the interview above, it was found that what was meant by internal coordination was the coordination carried out in the body of the organization (Polda Bengkulu) which involved the Finance and Planning Section in work units and the region. The coordination has been done so far, but its implementation must be continuously improved to 
be more effective and efficient.

2. The Forms of Sanctions Given by Itwasda in Responding to Work Units that Fulfill Tax Money

According to data obtained at the Bengkulu Regional Supervision Inspectorate in the field of tax evasion, the operandi modus was not to deposit tax funds that have been deducted. The treasurer deducted $P P h$ 22, $P P h$ 23 and PPn on Shopping Goods but did not deposit the tax withheld or collected to the State Treasury through the Bank or POS Office. When reviewed through article 372 of the Criminal Code the elements have been fulfilled because the treasurer as the perpetrator has deliberately made efforts against the law.

In this case there are special rules governing that in Article 38 verse (1) letter i of the General Taxation Provisions Act, the principle of lex specialis derogat legi generalis applies, in which the elements of the translation have been fulfilled and the sentence has the same sentence in the sound of article letter i, namely "Not depositing tax that has been withheld/collected" could be applied criminal sanctions against the Treasurer.

The repressive efforts were carried out as a last resort if preventive methods did not produce results, by emphasizing the principle of ultimum remedium repressive actions here rather than carrying out a series of investigative and investigative actions.

Instead, the sanction given to the financial functionaries was based on the Circular of the Minister of Administrative

Reform

Number:

SE/02/M.PAN/01/2005 dated January $7^{\text {th }}, 2005$ concerning the implementation of the follow-up of the APIP examination with details of classification: 01 of State Losses, 02 of Obligations to Deposit to the State/Region, 03 of Violations of Laws and Regulations, 04 of Violations of Work Procedures, 05 of Budget Disciplines, 06 of Obstacles to 
Programs and Activities, 07 of

Obstacles to Basic Duty and

Function, 08 of Administrative

Weaknesses, 09 of Community

Service Obstacles and 10 of

Deviations/Program/Activity

Target Violations. In the act of tax evasion must deposit back into the state treasury for noncompliance in managing and accountable namely number (02).

\section{CLOSING}

\section{Conclusion}

Based on the results of research and discussion on the role of the Bengkulu Regional Supervision Inspectorate in preventing tax evasion, the conclusions that can be made were: (1) Preventive activities (Prawasrik and Perwabkeu Verification Team) were held based on the number of findings related to tax evasion in 2019. In the implementation, it had been run well and effective because Bengkulu Regional Supervision Inspectorate has followed the mechanism set out in the Regulations related to supervision. In addition to being based on the existing regulations, the Bengkulu Regional Supervision Inspectorate has also sought to innovate in the form of activities such as prawasrik, forming a verification team for financial officers, and improving coordination of its substance as an effort to avoid tax evasion even though the verification team's activities still have some lackings that still need reconsideration. (2) In the repressive field, the role of the Bengkulu Regional Supervision Inspectorate was in the form of Wasrik by providing findings along with recommendations on the object of inspection. It has also been running optimally and still refers to the existing rules, and the result was the number of findings in the taxation field and the loss was increasingly reduced. So that the state revenue can be saved. Then the objective of supervision in order to realize operational management, human resources, infrastructure, and transparent and accountable financial budgets can be achieved.

\section{Suggestion}


Based on the conclusion above, the suggestions in this research were: (1) The Bengkulu Regional Supervision Inspectorate should continue to supervise since the beginning of the planning and budgeting that took place in each work unit so that the potential for tax evasion can be eliminated, and activities in the form of innovation to be increased. (2) The Bengkulu Regional Supervision Inspectorate should be permanent and capable of assisting and supervising any follow-up on the recommendations of the results of the activities that have been carried out on the work unit. This is intended so that any findings of deviations obtained from the results of supervision and inspection are actually followed up and corrected according to the recommendations that have been given by the Bengkulu Regional Supervision Inspectorate on these findings. (3) Developing the quality of resources through levels of education and training to improve the performance of the
Inspectorate as an Internal Control Apparatus in implementing SPIP. And optimally and build effective communication with the work unit and $B P K P$.

\section{Bibliography}

\section{Regulation}

Undang-Undang Nomor 2 Tahun 2002 Tentang Kepolisian Negara Republik Indonesia tanggal 8 Januari 2002

Undang-Undang Nomor 28 Tahun 2007 Tentang Ketentuan Umum dan Tata Cara Perpajakan tanggal 1 Januari 2008

Peraturan Pemerintah Nomor 53 Tahun 2010 tentang Disiplin Pegawai Negeri Sipil tanggal 6 Juni 2010.

Peraturan Kepala Kepolisian Republik Indonesia Nomor 18 Tahun 2011 Tentang Pengawasan dan Pemeriksaan Rutin di Lingkungan Kepolisian Republik Indonesia

Peraturan Kepala Kepolisian Republik Indonesia Nomor 4 Tahun 2014 Tentang Administrasi Pertanggungjawaban Keuangan di Lingkungan Kepolisian Negara Republik Indonesia tanggal 6 Februari 2014.

Peraturan Polisi Nomor 14 Tahun 2018 tentang Susunan Organisasi Tingkat Polda tanggal 21 September 2018

Peraturan Menteri Keuangan Nomor 132/PMK.02/2019 tentang Tata Cara Revisi Anggaran Tahun Anggaran 2019

\section{Books}


Divisi Pembina Hukum Polri, Buku I Penjabaran Unsur-unsur Pasal Dalam KUHP dan Resume Kasus, Mabes Polri, Jakarta 2003.

Soemardi \& Ibrahim Sastrawinata, Pendekatan Sistem Dalam Tugas Kepolisian, Mabes Polri, Jakarta, 2001.

Victor Sitorus dan Daissy Erdianthy, Sistem Pengendalian Manajemen, Modul Diklat Pembentukan Auditor Ahli, Pusat Pendidikan dan Pelatihan Pengawasan BPKP, Ciawi, 2007.

Bambang Waluyo. Penelitian Hukum Dalam Praktek. Jakarta: Sinar Grafika, 2008.

Saidi Muhammad Djafar, Perlindungan Hukum Wajib Pajak dalam Penyelesaian Sengketa Pajak. RajaGrafindo Persada, Jakarta 2008.

Dirdjosisworo Soedjono, Pengantar Ilmu Hukum. RajaGrafindo Persada, Jakarta 2008.

Muhammad Djafar Saidi dan Eka Merdekawati Djafar, Kejahatan di Bidang Perpajakan. RajaGrafindo Persada, Jakarta, 2012.

Salim HS dan Erlies Septiana Nurbaini, Penerapan Teori Hukum Pada Penelitian Tesis dan Disertasi. RajaGrafindo Persada, Jakarta, 2014.

Marpaung Leden, Asas-Teori-Praktek Hukum Pidana. Sinar Grafika, Jakarta, 2014.

Kunarto, Police Deviance (Penyimpangan Polisi). Cipta Manunggal, Jakarta, 1999.
Sitompul, Beberapa Tugas dan Wewenang Polri. Divisi Pembinaan Hukum Polri, Jakarta, 2004.

Chairul A Tubagus, Irma, Darra Amin. Hukum Pajak. Universitas Terbuka. Tangerang Selatan, 2019.

As Widodo, Polri dan Pemolisian Demokratis. Komisi Kepolisian Nasional. Trias Munarta. Jakarta, 2009.

Muhammad Farouk, Menuju Reformasi Polri. PTIK Press \& Restu Agung. Jakarta. 2005

Barda Nawawi Arief, Bunga Rampat Kebijakan Hukum Pidana (Perkembangan Penyusunan Konsep KUHP Baru). Kencana, Jakarta : 2016.

Lihawa Ronny, dkk, Implementasi Polmas di Empat Wilayah Polda. Komisi Kepolisian Nasional. Jakarta : 2009.

Ismail, Tjip. Hukum Pajak dan Acara Perpajakan, Universitas Terbuka. Tangerang Selatan, 2019.

Pratama Novrian, dkk. Provinsi Bengkulu dalam Angka (Bengkulu Provience In Figures) 2020. Badan Pusat Statistik Provinsi Bengkulu. Bengkulu.2020.

Ismail, Tjip. "Pajak Daerah dan Retribusi Daerah”. Universitas Terbuka. Tangerang Selatan. 2009

Mardiasmo, Perpajakan Edisi Revisi, Andi Publisher, Yogyakarta. 2018

Rismawati Sudirman, Antong Amiruddin, Perpajakan, Malang: Empat Dua Media,2012 
Zain, Mohammad. 2008. Manajemen Perpajakan Edisi 3, Jakarta: Salemba Empat.

Widi, widodo.2010. Moralitas, Budaya dan Kepatuhan Pajak. Bandung: Alfabeta.

Ely Suhayati., dan Siti Kurnia Rahayu. 2010. Perpajakan Indonesia : Konsep dan Aspek Formal, Yogyakarta : Graha Ilmu

Rahayu, Siti Kurnia. 2013. Perpajakan Indonesia: Konsep \& Aspek Formal Cetakan Kedua. Yogyakarta: Graha Ilmu.

\section{Rencana Strategis Kepolisian RI}

Makmur , Efektivitas Kebijakan Kelembagaan Pengawasan.Bandung PT. Refika Aditama. 2011. Hal

\section{Journal}

Sukriah, Ika Dkk. 2009. Pengaruh Pengalaman Kerja, Independensi, Obyekt ifitas, Integritas, dan Kompetensi terhadap Kualitas Hasil Pemeriksaan. Jurnal. Simposium Nasional Akuntansi XII. Palembang

Pulungan.2015. Pengaruh Keadilan, Sistem Perpajakan, Dan Kemungkinan Terdeteksinya Kecurangan Terhadap Persepsi Wajib Pajak Mengenai Etika Penggelapan Pajak (Tax Evasion). JOM FEKON Volume 2 No 1. Universitas Riau

Nurcolis. 2018. Efektivitas Sanksi Pidana Dalam Undang-Undang Ketentuan
Umum Perpajakan Dalam Menanggulangi Pengehindaran Pajak Korporasi. Jurnal Hukum dan Peradilan, Makasar ,Volume 7 Nomor 1, Maret $2018: 23-44$

Giyan Apandi dan Anom Wahyu Asmorojati. 2014. Peranan Polisi Lalu Lintas dalam Meningkatkan Kedisiplinan Berlalu Lintas Pengguna Kendaraan Bermotor di Wilayah Kepolisian Resort Bantul. Jurnal Citizenship, Yogyakarta, Volume 4 Nomor 1, Juli 2014. Universitas Ahmad Dahlan.

Megawati Barthos. 2018. Peran Polisi Lalu Lintas Dalam Meningkatkan Kesadaran Hukum Pengendara Sepeda Motor Di Wilayah Polres Jakarta Pusat Berdasarkan UndangUndang Nomor 22 Tahun 2009 Tentang Lalu Lintas Dan Angkutan Jalan. Lex Librum. Jakarta, Volume 4 Nomor 2 Juni 2018 Page: 739 - 757 . Universitas Borobudur Jakarta.

\section{Intenet}

https://sites.google.com/site/pemeriksaand anpenyidikanpajak/artikelpajak/mem ahami-penyidikan-tindak-pidana-dibidang-perpajakan. Diakses pada 24 Maret 2020.

https://news.ddtc.co.id/menegaskankembali-asas-ultimum-remedium-19218. Diakses pada 14 Mei 2020 